\section{EVOLUTIONS IN VIRGIN COCONUT OIL: LIQUID TO POWDER}

Nor Farahiyah Aman Nora, Harisun Ya'akoba,b*, Ani Idrisa,b, Sulaiman Ngadirana, Nurarbainah Shamsul Anuarc, Mohamad Roji Sarmidid

anstitute of Bioproduct Development, Universiti Teknologi Malaysia, 81310 UTM Johor Bahru, Johor, Malaysia bSchool of Chemical and Energy Engineering, Universiti Teknologi Malaysia, 81310 UTM Johor Bahru, Johor, Malaysia cHealth and Wellness Alliance, Universiti Teknologi Malaysia, 81310 UTM Johor Bahru, Johor, Malaysia Innovation Centre in Agritechnology for Advanced Bioprocess, Universiti Teknologi Malaysia-Pagoh, Jalan EDU-hub UTM 2, 84600 Muar, Johor, Malaysia
Article history

Received

1 November 2020

Received in revised form

22 March 2021

Accepted

30 March 2021

Published online

22 April 2021

*Corresponding author harisun@ibd.utm.my

\section{Graphical abstract}

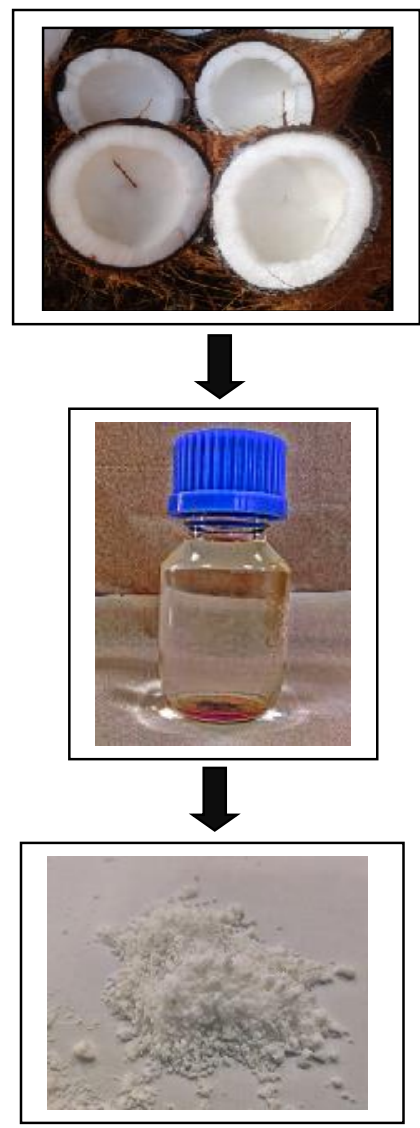

\section{Abstract}

Awareness of virgin coconut oil (VCO) as a functional food supplement has grown enormously. The treatment of raw material and processing parameters is crucial as they affect the overall yield and quality of the oil. Meanwhile, the microencapsulation technology offers better handling, good oxidative stability, and longer shelf life of the VCO powder. Although good quality liquid and powdered oils can be obtained through sophisticated methods, the process involved is expensive and required high maintenance. By utilising dry kernel and coconut milk-based extractions methods, high-grade quality of VCO can be achieved. During microencapsulation, the spray drying method can preserve the phenolic and antioxidant compounds and maintain the low rancidity of the VCO. This paper evaluates the recent findings of the oil extraction methods and the development of VCO microencapsulation. These methods offer good quality, reproducible and economic viability.

Keywords: Virgin coconut oil, extraction method, microencapsulation, spray drying

\section{Abstrak}

Kesedaran terhadap minyak kelapa dara (VCO) sebagai makanan tambahan berfungsi telah berkembang pesat. Perawatan bahan mentah dan parameter pemprosesan adalah penting dalam mempengaruhi hasil keseluruhan dan kualiti minyak. Sementara itu, teknologi mikroenkapsulasi menawarkan pengendalian yang lebih baik, kestabilan pengoksidaan yang baik dan jangka hayat serbuk VCO yang lebih lama. Walaupun kualiti minyak dalam bentuk cecair dan serbuk boleh diperolehi melalui kaedah-kaedah yang canggih, proses yang terlibat kebiasaanya lebih mahal dan memerlukan penyelenggaraan yang lebih tinggi. Dengan menggunakan kaedah pengekstrakan berasaskan isirung kering dan santan kelapa, VCO dengan kualiti yang baik akan diperoleh. Semasa mikroenkapsulasi, kaedah semburan kering mampu memelihara sebatian fenolik dan antioksidan dan mengekalkan paras ketengikan VCO yang rendah. Kajian ini menilai penemuan terbaharu mengenai kaedah pengekstrakan minyak dan perkembangan mikroenkapsulasi dalam VCO. Kaedah-kaedah ini memberikan kualiti yang baik, boleh dihasilkan semula dan ekonomi

Kata kunci: Minyak kelapa dara, kaedah pengestrakan, mikroencapsulasi, pengeringan sembur

(c) 2021 Penerbit UTM Press. All rights reserved 


\subsection{INTRODUCTION}

The trends for healthy food ingredients and products have increased due to people's awareness. As society becomes more affluent, people become more healthconscious and concerned about what they consume and the benefits they can derive from it. Coconut oil consistently flourishes in the pharmaceutical, nutraceutical, and cosmeceutical industries. Due to its wide range of applications, the global demand for coconut oil is growing significantly, and the situation has positively impacted economic value [1]. Since the introduction of VCO to local and international markets, the demands for coconuts increase exponentially. The global market for VCO stood at $\$ 2.7$ billion (2018) and is expected to expand at a CAGR of over $9 \%$, reaching $\$ 4.7$ billion (2024) [2].

As VCO consists of high saturated fatty acids, its role in human health has always been misrepresented. It is noteworthy that not all saturated fats are associated with the risk of diet-related non - communicable diseases. The saturated fats are differentiated according to their biochemical, physicochemical, and physiological characteristics [3]. The high level of medium-chain saturated fatty acid (MCFA) present in VCO showed significant improvements in human health, such as the availability of dietary supplements for patients suffering from fat-absorption disease, antiobesity treatment, and the reduction of total blood cholesterol [4].

The coconut oil derived from copra offers high recovery. However, it must be refined, bleached, and deodorised (RBD) to be suitably used in the market due to its unfavourable aroma and taste. However, several coconut producing countries emphasised that the RBD stage is unnecessary in VCO production [5]. This basis is because VCO must be processed from a fresh and mature kernel of coconut, technically by processing using natural means with or without the application of heat, without undergoing chemical refining, and so that it does not lead to the alteration of the natural state of the oil [6]. Several other extraction methods have been developed to produce a high degree of recovery with good quality VCO. The VCO processing is initiated either from coconut kernel or coconut milk. The dry method utilises the coconut kernel in the processing, whereas coconut milk is used in the wet, integrated wet, cold-pressed, hot-processing, fermentation, and enzymatic processes [7]. All these methods contribute to different yield and quality of the oil produced.

In its original state, the oil-based form of VCO is insoluble in water and creates limitations in food application. On the other hand, the liquid form of VCO is also messier, less convenient, more likely to spill, and more difficult to transport than the powdered form of VCO. Furthermore, in the presence of moisture, oxygen, heat, and light, the oxidation of liquid oil during storage, the oil will turn rancid. This rancidity will reduce the presence of high free fatty acid and peroxide values and alter the oil to an unpleasant aroma and 'sour' taste. Coconut oil powder-based products are also available in the market, namely coconut creamer, medium-chain triglycerides (MCT) powder, and many others. The lingering question is whether all these products have the same characteristic as virgin coconut oil? Therefore, microencapsulated VCO in the powder form will mitigate these hurdles and offer a broader application in the product formulation than the liquid form VCO. Microencapsulation technology facilitates the challenge of providing unspoiled healthy ingredients into food without compromising its bioavailability and functionality, improving the shelf life of an encapsulated product, and increasing its thermostability and oxidative stability [8], [9]. The drying methods are crucial to obtain good powder characteristics, including spray-drying, spray-chilling, freeze-drying (lyophilisation), and fluidised bed coating [10], [11]. Figure 1 shows the development of VCO from liquid to powder. The active ingredient is diffused through the wall material [9]. Subsequently, the mixture of the active ingredient and the wall material is converted into an emulsion. The preparation of the emulsion preparation and dispersion homogeneity are essential in the oil microencapsulation technology, as the adsorption of liquid-liquid interfaces has a pronounced effect on the stability of the emulsion [8], [12], [13]. Spray-drying is a microencapsulation technique widely used in the food industry as it provides low cost and availability of the equipment [14]. This process yields $\mathrm{VCO}$ powdered form with low water activity, high quality, and good storage capability [15]. (a)

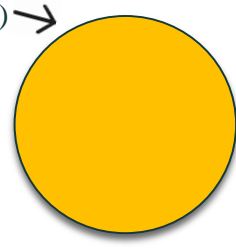

(i) Liquid VCO

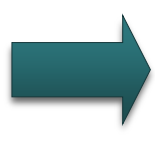

(ii) Emulsified VCO

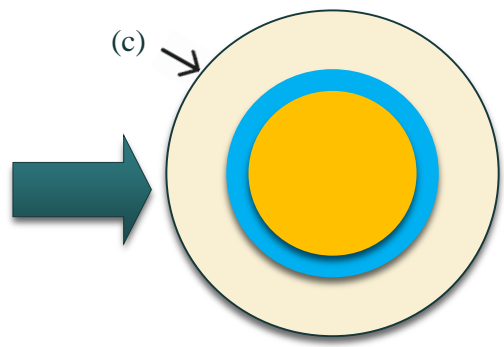

(iii) Microencapsulated VCO

Figure 1 Form of VCO. Symbol indicated: (a) oil drop, (b) emulsifying agent, and (c) wall material 
This paper emphasises on:

(1) The general definition of the processing methods involved in the production of VCO.

(2) The general discussion on the yield and quality of the VCO.

(3) The parameters involved during the microencapsulation process and the quality of the powder produced.

\subsection{COCONUT OIL OBTENTION}

Typically, coconut has a maximum of $75 \%$ oil content [16]. A production with a high oil recovery without compromising its quality is a significant concern in methodological strategy. By employing the drying method, $65 \%$ of oil can be extracted from the copra [7]. However, the copra needs a few months of drying (sun drying) or using high temperatures (smoke drying). Consequently, this method struggles with oxidative rancidity and aflatoxin contamination, eliminating its natural colour and aroma [17]. As a result, the RBD process is introduced to overcome this problem, resulting in a tasteless, odourless, and clear appearance [1]. The RBD process is not a practical approach in producing high-quality functional oils such as VCO, as it may degrade some of the nutrients [17], [18]. The RBD oil is not considered as VCO due to the usage of chemicals and high temperatures in the process [7].

\subsection{Dry Method}

The dry method is when the coconut kernel was dried at $60^{\circ} \mathrm{C}$ before extraction and further dried at $65^{\circ} \mathrm{C}$. The VCO yield obtained from this method was $25 \%$ which was relatively lower than RBD oil. However, it could preserve the minor compounds such as a-tocopherol and polyphenols, reflecting the increased activity of antioxidant enzymes and inhibited lipid peroxidation [19], [20]. This outcome was expected when a lower temperature was used, and instant drying may preserve the minor compounds in VCO compared to copra oil [21].

\subsection{Wet Method}

Another extraction method of $\mathrm{VCO}$ is the wet method which utilises coconut milk during its extraction process. The coconut meat is processed into coconut slurry and pressed using a cloth to obtain the coconut milk. The coconut milk is then refrigerated and heated to obtain the VCO [19]. As coconut milk produces stable emulsion, an external force is needed to break it. The emulsion stability was due to coconut proteins such as albumins, globulins, and phospholipids. These proteins are partially present in the aqueous process of coconut milk, which interacts with the fat globules and functions as an emulsifier by coating their surfaces [22].

Coconut milk can be destabilised using several mechanisms, such as cremation, flocculation, and coalescence. Figure 2 shows the destabilising mechanism of the emulsion. Creaming (or settling) is a separation phenomenon that occurred due to the differences in density between two phases due to the force of gravity [23]. The oil phase travels as clusters but does not separate the oil globules, and the arrangement of the particles remains intact. The weak attractive forces between the colloids produce flocculation behaviour [24]. Eventually, the coalescence-movement takes place slowly, and the interfacial oil globules are ruptured, allowing the globules to merge [25]. By cooling the emulsion at an appropriate temperature that exceeds the energy barrier, the emulsion continues to destabilise as fat crystals from the oil droplets behave as the nucleus, continually penetrates the neighbourhood droplet, causing partial coalescence. As a result, the emulsion will be destabilised [26]. Partial coalescence alters the oil - in - water phase (O/W) to the phase separation during the churning process [27]. The wet method also exhibited good preservation of the minor compounds [19]. However, the oil yield is relatively lower than the dry method since the oil/water separation efficiency contributes to the higher oil recovery [28].

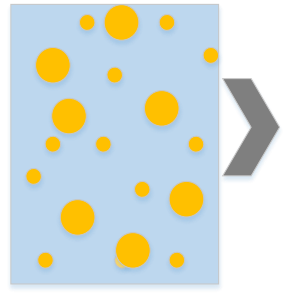

Coconut milk

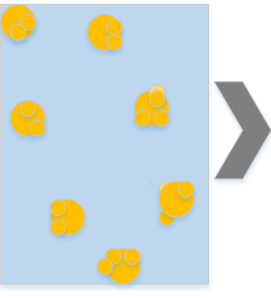

Flocculation

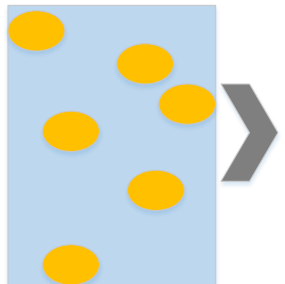

Coalescence

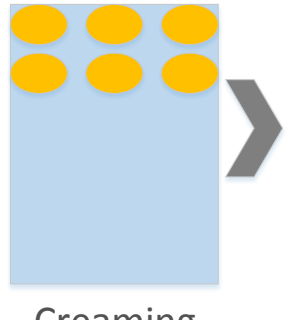

Creaming

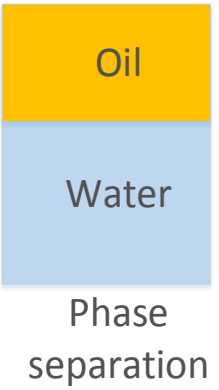

Figure 2 The de-emulsification mechanism of coconut milk

\subsection{Integrated Wet Process}

The integrated wet process combines cooling, freezing, thawing, and centrifugation procedures. Firstly, coconut milk will undergo the cooling process to break down the oil/water emulsion at a temperature between $5-10^{\circ} \mathrm{C}$ [24], [29]-[31]. Better recovery of coconut oil is achieved at a lower cooling temperature. It is, therefore, essential to determine the correct cooling temperature for the processing of coconut oil [22]. 
Additionally, mechanical aid, such as agitation during the churning process, accelerates the de-emulsification of coconut milk [31]. The thawing process also destabilises coconut emulsion as it deformed the protein when heated [26]. During this process, the fat crystal coalesces and turns into the water - in - oil emulsion [32]. The subsequent centrifugation process is required to remove unwanted residues in coconut oil [33]. The quantity of oil yield from the integrated wet process was $85 \%$ higher than the fermentation method (without adding any bacteria or enzymes) but relatively lower than the dry method. The churning process of converting the coconut milk to butter has increased the water removal from coconut milk and may retain its nutty flavour and aroma [34].

\subsection{Cold Process}

The cold extraction involves cooling the coconut milk at low temperatures $\left(2-8^{\circ} \mathrm{C}\right)$. The oil-water phase is then separated by the centrifugation and filtration of the oil [7]. Another method is to heat the coconut milk at 100 $-120^{\circ} \mathrm{C}$ to evaporate the water, followed by a decantation cycle to extract the oil. The VCO recovery in the hot condition is lower than the cold condition [22].

\subsection{Fermentation Process}

The fermentation method could be done by naturally separating the oil from water by fermenting the coconut milk, and, after some time, it will breaks into an emulsion [20], [35]. Microbial fermentation can separate the oil and other coconut milk emulsion elements such as protein [36]. In this method, the selection of bacteria plays a vital role in obtaining a high coconut oil recovery level. For instance, the Lactobacillus planatarum showed better emulsion breaking capacity than Lactobacillus delbrueckii due to its ability to multiply faster in coconut milk during the fermentation process. Saccharomyces cerevisiae also had been successfully used to extract the coconut oil. The bacteria release lipase and protease enzymes to break the coconut milk emulsion [37]. The maximum yields of $21-37 \%$ were also recorded by the fermentation method [36],[38]. The enzymatic extraction is performed by adding enzymes in the coconut milk emulsion to expedite sedimentation/fermentation in the aqueous system. Using Viscozyme L and Neutrase 1.5 MG, 83\% of the protein-oil emulsion was successfully achieved [39]. The use of a-amylase, cellulase, protease, and polygalacturonase enzymes also contributed to quite a significant amount of oil yield (42\%) [40]. The a-amylase helped to hydrolyse the a-linkages to liquefy the starch compound and produce maltose. Simultaneously, polygalacturonase hydrolyses the a-linkages of polygalacturonic acid compounds from the end of the polymer, and the function of the protease enzyme is to hydrolyse the plant protein [41].

\subsection{Fatty Acid and Triglyceride Composition in Virgin Coconut Oil}

Saturated fatty acids can be differentiated based on physicochemical, physiological, and biochemical interpretive [3], [42]. Naturally, the medium-chain fatty acids (MCFAs) in VCO are bond together as mediumchain triglycerides (MCT) [43]. he MCT principally consists of capryolic acid/hexanoic acid (C6), caprylic acid/octanoic acid (C8), capric acid/decanoic acid (C10) and lauric acid/dodecanoic acid (C12) [44]-[48]. As the MCT is the primary triglyceride component, the MCFA terminology focuses on its physiological and metabolic functions. Proportionally, the MCFA comprises fatty acids from C6 to C12 [49]-[51]. In comparison, C14 (myristic acid/tetradecanoic acid) and above are known as long-chain fatty acids (LCFA) [44], [52]. The coconut oil consisting of more than $65 \%$ MCFA is also known as MCFA oil [3]. Thus, all studies [17], [20], [53]-[59] showed a presence of at least $55 \%$ of MCFA (Table 1), and this can be considered as MCFA oil. The variability of fatty acid content in coconut oil was due to the coconut variety, the sample preparation, the state of processing, and the processing method.

Table 1 Fatty acid composition in coconut oil

\begin{tabular}{llllllllll}
\hline \multicolumn{1}{c}{ Method } & C6:0 & C8:0 & C10:0 & C12:0 & C14:0 & C16:0 & C18:0 & C18:1 & C18:2 \\
\hline RBD [17] & 0.63 & 8.24 & 6.53 & 47.42 & 18.26 & 9.33 & 2.68 & 5.25 & 1.57 \\
RBD [53] & NM & 7.24 & 5.25 & 50.90 & 21.38 & 9.22 & 0.38 & 4.81 & 0.81 \\
Dry [54] & 0.48 & 7.21 & 6.24 & 48.96 & 18.28 & 7.70 & \multicolumn{2}{c}{ Total 6.56 } & 3.26 \\
Dry [55] & 0.11 & 5.45 & 5.42 & 51.35 & 19.74 & 8.09 & 2.49 & 5.62 & 1.11 \\
Cold-pressed [20] & 0.70 & 6.67 & 5.58 & 48.18 & 20.40 & 8.78 & 3.71 & 5.75 & 1.10 \\
Integrated wet & 0.40 & 6.05 & 5.77 & 50.93 & 19.40 & 8.17 & 2.82 & 5.23 & 1.10 \\
[60] & & & & & & & & & \\
Enzymatic [56] & 0.52 & 6.63 & 5.49 & 46.36 & 19.54 & 9.94 & 3.37 & 6.50 & 1.63 \\
Enzymatic [57] & $\mathrm{NM}$ & 6.3 & 5.4 & 48.8 & 20.0 & 9.8 & 3.6 & 5.4 & 0.6 \\
Fermentation [56] & 0.57 & 7.21 & 6.07 & 48.42 & 18.75 & 9.06 & 3.15 & 6.35 & 1.36 \\
Fermentation [58] & $\mathrm{NM}$ & 9.7 & 6.4 & 49.2 & 19.5 & 7.0 & 2.3 & 4.7 & 1.1 \\
\hline
\end{tabular}




\subsection{Phenolic Compound in Virgin Coconut Oil}

The presence of phenolic acid shows its antioxidant potential, allowing it to be used in the food and nutraceutical industries [61], [62]. The minor compound of phenolic acid exhibits antioxidant properties of antimutagenic, antiproliferative, and anticarcinogenic, benefiting human beings. In VCO, the phenolic compounds identified are ferulic, p-coumaric, sinapic, and caffeic acids [17], [63]. These phenolic compounds have exhibited strong antioxidant capability towards free radicals [64], [65]. The VCO produced by wet methods contains higher biologically active compounds such as polyphenol $184 \mathrm{mg}$ GAE/100g oil), which reflected an increased antioxidant activity and inhibited the peroxidation of lipids compared to copra oil (64.4 mg/100g oil) [19]. The cold-pressing process indicated a-tocopherol, phenolic compound, and antioxidant capacity $15.4 \mathrm{mg} / 100 \mathrm{~g}$, $57.8 \mathrm{mg} \mathrm{GAE} / 100 \mathrm{~g}, 0.48 \mathrm{mg}$ GAE/ml).

Meanwhile, the fermentation process showed a lower concentration of compounds $(4.7 \mathrm{mg} / 100 \mathrm{~g}, 53.7$ mg GAE/100g, $0.81 \mathrm{mg} \mathrm{GAE} / \mathrm{ml}$ ). The lower tocopherol suggested that a longer fermentation process caused the coconut oil oxidation during the process. Meanwhile, the lower phenolic compound was due to the phenolic polarity causing it to dissolve at the aqueous layer of the oil/water phase during the fermentation period, which lost during oil collection [20]. The phenolic compound concentration and antioxidant capacity were also higher in hot conditions at $100-120^{\circ} \mathrm{C}(44.9 \mathrm{mg} \mathrm{GAE} / 100 \mathrm{~g}, 0.05 \mathrm{mg} \mathrm{GAE} / \mathrm{ml})$ (44.9 $\mathrm{mg} \mathrm{GAE} / 100 \mathrm{~g}, 0.05 \mathrm{mg} \mathrm{GAE} / \mathrm{ml}$ ) than in cold conditions at $10^{\circ} \mathrm{C}(6.6 \mathrm{mg} \mathrm{GAE} / 100 \mathrm{~g}, 0.03 \mathrm{mg} \mathrm{GAE} / \mathrm{ml}$ oil). This circumstance could be due to the evaporation of water in the coconut milk during the process, which increased the phenolic concentration in the coconut oil [25], [66]. The integrated wet process showed the least amount of phenolic compound (20mg GAE/ 100g) but the highest antioxidant content $(0.005 \mathrm{mg} \mathrm{GAE} / \mathrm{ml})$ [60].

From all the studies, the high antioxidant properties were not reflected by the high phenolic content in $\mathrm{VCO}$, as it is subjected to the functional group in the phenolic compound. Therefore, the phenolics' concentration and consistency are essential for determining the antioxidant capacity in VCO [66]. Instead of variations in the type of processing, the differences in tocopherol, phenolic compounds, and antioxidants can be related to different processing parameters, preparation of samples, coconut variety used, storage time, and condition [60], [67], [68].

\subsection{Oil Rancidity}

Several parameters, such as peroxide value, acid value, ester value, and saponification value, are vital in determining the oil's physicochemical properties [69]. The moisture content showed the amount of water remaining in the coconut oil. In compliance with the Malaysian Standards for virgin coconut oil, coconut oil's moisture content shall not exceed $0.15 \%$ [70]. Hydrolytic rancidity decreases the pleasant aroma and flavour of coconut oil and can be tested with a high free fatty acid content. The Malaysia Standards emphasised that free fatty acids must not exceed $0.5 \%$ [70]. The peroxide value shows the early stage of oxidation in the oil by reacting with oxygen in the atmosphere and producing hydroperoxide. The oxidation of unsaturated fatty acids (C18:1 and C18:2) is due to high temperature or long storage duration. The low amount of peroxide will ensure the freshness of the oil produced. From the Malaysia Standards, the peroxide value must be less than $3 \mathrm{meq} / \mathrm{kg}$ [70]. The iodine value indicates the degree of the unsaturation of the oil. High iodine value is undesirable due to the high rancidity of oil [71]. The Malaysia Standards also stated that the amount of 5.510.6 is acceptable for iodine value [70]. Saponification values stated the amount of short-chain fatty acids in the oil [53]. It is useful to determine the mean weight of acid, quantity, and type of glycerides and adulteration in oil [72]. The saponification value of $248-265 \mathrm{mgKOH} / \mathrm{g}$ oil is set for virgin coconut oil under Malaysia Standards [70].

From Table 2, the moisture content of all the methods is acceptable except for the centrifugation and fermentation methods. The speed of centrifugation and fermentation was suspected for the increasing oil moisture [40]. In the meantime, high levels of free fatty acid have been detected in RBD and copra oils. The high amount of free fatty acid may be caused by inadequate copra storage, high temperature, and high oil moisture content [53], [76]. The high moisture content due to the fermentation method also suggested a high free fatty acid value. This condition was influenced by changes in acidity due to the longer fermentation time [40]. Low peroxide and iodine values were also seen in all coconut oil production methods compared to the Malaysia Standards. The low peroxide does not help any oxidative degradation of the oil. Variation of findings for the same coconut oil production methods can also be observed, for example, in fermentation and enzymatic processes, the different uses of bacteria, enzymes, their concentrations resulting from the differences of hydrolysis reactions to discharge the water [75]. All the methods discussed also showed that the saponification values fell within Malaysia Standards, indicating good oil purity [72]. 
Table 2 The physicochemical properties of coconut oil

\begin{tabular}{|c|c|c|c|c|c|}
\hline Method & $\begin{array}{c}\text { Moisture } \\
\text { content } \\
(\%) \\
\end{array}$ & $\begin{array}{c}\text { Free fatty } \\
\text { Acid } \\
\text { (\%) } \\
\end{array}$ & $\begin{array}{c}\text { Peroxide value } \\
\text { (mequiv. } \\
\text { oxygen/kg) }\end{array}$ & $\begin{array}{l}\text { lodine } \\
\text { value }\end{array}$ & $\begin{array}{c}\text { Saponification value } \\
\text { (mg KOH/g oil) }\end{array}$ \\
\hline RBD [53] & - & 0.530 & 0.000 & 6.00 & 255.90 \\
\hline RBD [71] & $0.01-0.10$ & $0.01-0.08$ & $0.27-0.8$ & $6.81-8.91$ & - \\
\hline Copra [71] & $0.08-0.14$ & $0.66-2.50$ & $0.72-2.77$ & $6.61-7.31$ & - \\
\hline Copra [56] & 0.040 & 0.46 & - & 4.18 & 258.42 \\
\hline $\begin{array}{ll}\text { Chilling } & \text { and } \\
\text { thawing [40] } & \end{array}$ & 0.15 & 0.08 & 0.43 & - & 261.00 \\
\hline Centrifugation [40] & 0.34 & 0.17 & 0.34 & - & 250.00 \\
\hline Fermentation [73] & - & 0.15 & 0.78 & 7.26 & 262.77 \\
\hline Fermentation [74] & 0.30 & 0.22 & 2.540 & - & - \\
\hline Fermentation [35] & 0.013 & 0.04 & 2.550 & 3.10 & - \\
\hline Enzymatic [41] & 0.110 & 0.05 & 0.017 & 8.30 & 261.00 \\
\hline Enzymatic [57] & 0.110 & 0.23 & 0.200 & 4.13 & 258.30 \\
\hline Enzymatic [75] & $0.06-0.12$ & $0.34-0.40$ & 0.01 & $2.41-2.44$ & - \\
\hline Enzymatic [40] & 0.39 & 3.28 & 0.43 & - & 259 \\
\hline
\end{tabular}

\subsection{MICROENCAPSULATION OF VCO}

Generally, the technique for making microcapsules involves four main steps. (i) Selecting the best encapsulating material. The materials used for encapsulation should be food-grade quality, has good emulsifying properties, low viscosity, and good film creator [77]. (ii) The homogenisation of the emulsion consists of the target component and the supporting materials of the wall materials. Therefore, the optimisation of the emulsion parameters is necessary to obtain adequate and stable droplets of oil [78]. (iii) Hot air was inserted into the atomised particle through the nozzle or spinning wheels. The atomisation is crucial as it significantly affects the chemical composition of the particle's surface in the spray drying process. (iv) Collection and air-tightening the produced powder [79]. Such steps are beneficial during the encapsulation of sensitive ingredients such as oil, as they contain a high amount of nutritionally valuable components, including antioxidants, bioactive phenolics, and essential fatty acids. Note that the enhancement of encapsulation efficiency is another critical objective in encapsulation technology. The efficiency reflects the presence of an oil phase on the surface finished powder particles, as shown by the wall material's ability to prevent leakage of the inner oil phase due to the leaching process [80].

In the previous study, the VCO was successfully encapsulated using respective spray drying and supercritical carbon dioxide spray drying $\left(\mathrm{SC}-\mathrm{CO}_{2}\right)$ [81][84]. The ability to protect the antioxidant properties and provide less rancidity of the VCO, like liquid form, is also desired during the microencapsulation process. As there were limited studies on VCO microencapsulation, a few related research are discussed here to understand VCO powder's microencapsulation better.

\subsection{Selection of Encapsulation Materials}

The preparation of the emulsion is the initial step that must be taken before the drying process. The emulsion must have good homogeneity, provides stability and low viscosity to ensure the oil droplets is protected by the emulsifying film and can be dried correctly during spray drying. Therefore, selecting the wall materials is crucial as it alters the emulsion properties and microencapsulation performance. The wall material, also referred to as a coating material, is made of natural or modified polysaccharides, proteins, sugars, gums, lipids, and synthetic polymers [85], [86]. It is expected to protect the bioactive compounds from environmental degradation. The requirements for the wall material used must be food-grade, and the addition of wall material leads to higher stability of the oil - in - water emulsion [10]. For instance, maltodextrin, which originated from starch, is widely used as it is an inexpensive material, possessed high water-soluble and has low viscosity at high concentration [87]. Meanwhile, the addition of gum Arabic to sodium caseinate and maltodextrin mixture during emulsification can preserve better antioxidant capacity for about $80 \%$ in the liquid VCO but lower encapsulation efficiency compared to without the addition of gum Arabic. The addition of gum Arabic preserved the volatile compound, increased the emulsion viscosity, enlarged the particle size, and increased the surface oil that leads to the oxidation of the oil [81], [88]. Another option available 
is the usage of agave inulin as wall materials which offers a reduction in surfactant used and provides a healthier benefit [88].

Due to its drawback of poor surface active of wall materials, the incorporation of emulsifiers such as sodium caseinate, whey protein concentrate, gelatine, or surfactant could reduce the interfacial tension, therefore, stabilised the binding properties to the oil [88]. For non-ionic surfactants such as Tweens and Spans, both can reduce the interfacial tension between the two-immiscible oil/water system and the droplets' size [89]. The surfactant is an amphiphile that has an equilibrium in lipophilic and hydrophilic states. Surfactants are molecules that can form micelles. The lipophilic portion of the surfactant connects to the interior, and the hydrophilic part is facing the aqueous solution. The hydrophilic-lipophilic balance (HLB) is a predictive approach to the emulsifying characteristics for emulsifiers except for its efficiency, ranging from 0 20, specifically for non-ionic surfactants [90]. Different surfactants originating from different chemical groups have different polarities, contributing to the different wetting capacity [91]. For example, Tween 80 (HLB 15.0) showed a better emulsifying capability compared to Tween 20 (HLB 16.7) and Tween 40 (HLB 15.6) at a ratio of oil to the water of 2:8 in the VCO emulsion [92]. Therefore, the combination of wall materials and emulsifying agents have increased the stability of an emulsion. For example, maltodextrin, $3.5 \%$ sodium caseinate, and $3.5 \%$ of gelatine showed good stability during $\mathrm{VCO}$ microencapsulation [81]. For other coconut-based products, the introduction of guar gum (1\%) and Tween 60 (1\%) was seen to improve the stability of the emulsion and thus reduced the size of the droplets when coconut milk powder was encapsulated using a spray dryer [93]. Good stability of the emulsion was also reported with the addition of Tween $20(0.5 \%)$, which minimised the partial coalescence phenomenon in the O/W formulation of palm kernel and canola oils [94]. The positive correlation between wall materials usage and emulsifying agents with emulsion stability is also emphasised [95], [96].

Often, when excess wall material or surfactant is added to the emulsion, it can remain free in the aqueous phase and cause a decrease in the emulsion. This condition will result in the flocculation and coalescence of oil droplets. The excessive usage of surfactants can be measured by critical micelle concentration and critical coagulation concentration [97]. Excess emulsifier negatively affects micelles' development, which would later interfere with active ingredients such as phenolic, thereby altering the partitioning between the different phases of emulsion and the role of the active ingredients [88].

The encapsulation efficiencies can also be affected by the viscosity of the emulsion, which determines the flow resistance of the emulsion [88]. When an emulsion fluid moves through a surface, the heat transfer between the hot air from the spray dryer and the emulsion creates the convective heat transfer. Therefore, the speed of the fluid is one of the essential parameters to hasten the drying of the particles. Higher viscosity reduces the speed of the emulsion movement [98].

The viscosity is significantly influenced by the concentration of an emulsion [99]. During the emulsion preparation, the total concentration of solid content in the emulsion significantly impacted the encapsulation's efficiency. It will be part of the wall structure supporting the microcapsules during the drying process [100]. Generally, the ratios of 1:1 to 1:10 of oil: wall material are required to ensure the encapsulation's efficiency [101]. For instance, the ratios of 1: 1.45 to 4.00 were used during the emulsification of VCO [81], [83]. Instead of the ratio mentioned, the emulsification must be supported with a good wall material to obtain a good microencapsulation efficiency. For example, the utilisation of gum Arabic (10-20\% from total solid) increased the total solid content and yielded approximately $30 \%$ of the babassu coconut powder [102]. The increase was due to the low viscosity, high solubility, and the ability to retain volatile compounds that make gum Arabic suitable for wall material in encapsulation [103]. Conversely, the usage of maltodextrin (40-45\% of total solid) in the formulation of encapsulated coconut milk yielded only $4.6 \%$ [104]. However, the ratio of each wall solid content and wall and core materials were relatively to give lesser impact during the encapsulation of VCO compared to the effect of emulsifying and spray drying processing conditions [83], [105].

\subsection{Homogenisation}

The observation of the homogenisation process is essential to determine a good encapsulation of VCO. The homogenisation process using mechanical force, such as homogeniser, was used to transform the two immiscible liquids into an emulsion. A smaller droplet size was desired to increase the emulsion's physical stability during homogenisation [106].

The type of homogeniser and homogenisation duration are crucial to obtain a monodispersed particle size [107]. Homogenizers, namely high shear disperser, rotor-stator, ultrasonic, and high-pressure, are commonly used to provide energy to deform droplets and increased the interfacial area [12]. Besides converting the liquids into an emulsion, homogenisation reduces the size of the emulsion [108]. The high-pressure usage up to 300 bar improvised the droplet size by more than $50 \%$ reduction compared to the lower pressure of 30-50 bar [12], [88]. In contrast, the homogenisation pressure (400-600 bars) was insignificant to the droplet size unless it increases the oil fraction's aroma [109]. Table 3 explained the effects of the formulation and homogenisation process on the droplet size produced. 
Table 3 Effect of homogenisation process in oil-in-water emulsion

\begin{tabular}{|c|c|c|c|c|c|c|}
\hline Material & $\begin{array}{l}\text { Homogenisation } \\
\text { procedure }\end{array}$ & Formulation & $\begin{array}{c}\text { HLB } \\
\text { Values }\end{array}$ & $\begin{array}{l}\text { Z- } \\
\text { average(n } \\
m\end{array}$ & $\begin{array}{l}\text { Average } \\
\text { particle size } \\
(\mathrm{nm})\end{array}$ & Observation \\
\hline VCO [1 10] & $\begin{array}{c}\text { Prehomogenized at } \\
12,000 \text { rpm, } 2 \text { minutes, } \\
\text { followed by } \\
\text { ultrasonication at } 60 \% \\
\text { powder intensity } \backslash \text { for } \\
3 \text { minutes }\end{array}$ & $\begin{array}{l}2.5 \% \text { consists of } \\
\text { Tween } 80 \text { and } \\
\text { soy lecithin }\end{array}$ & - & -47.5 & 608.00 & $\begin{array}{l}\text { Good entrapment of } \\
\text { vCO droplets and good } \\
\text { stability of the emulsion. }\end{array}$ \\
\hline Clove oil [ [llll] & $\begin{array}{c}\text { Ultrasonication at } 5 \\
\text { minutes, duty cycle at } \\
0.75 \% \text { and intensity at } \\
208 \mathrm{~W} / \mathrm{cm}^{2}\end{array}$ & $\begin{array}{l}5 \% \text { consists of } \\
\text { Tween } 80 \text { and } \\
\text { Span } 80\end{array}$ & 9 & - & 43.00 & $\begin{array}{l}\text { Good stability of } \\
\text { nanoemulsion was } \\
\text { achieved. }\end{array}$ \\
\hline $\begin{array}{l}\text { Poly(lactic } \\
\text { acid) [1 } 112]\end{array}$ & $\begin{array}{c}\text { Double sonication to } \\
\text { achieve double } \\
\text { emulsion }\end{array}$ & $\begin{array}{l}\text { 5\% polyvinyl } \\
\text { alcohol, }\end{array}$ & -4.4 & 200 & 200 & $\begin{array}{l}\text { Low dispersity of } \\
\text { nanodroplets } \\
\text { achieved. }\end{array}$ \\
\hline $\begin{array}{l}\text { Avocado oil } \\
\text { [113] }\end{array}$ & $\begin{array}{l}\text { Premix using magnetic } \\
\text { stirring at } 200 \text { rpm for } \\
10 \text { minutes, followed } \\
\text { by high-speed } \\
\text { homogenising at } \\
16,800 \text { rpm for } 15 \\
\text { minutes. Finally, } \\
\text { sonication at } 20 \mathrm{kHz} \\
\text { for } 20 \text { minutes. }\end{array}$ & $\begin{array}{c}\text { 7.5-10\% Tween } \\
80\end{array}$ & - & -26 to-59 & $103-249$ & $\begin{array}{l}\text { Good oxidative stability } \\
\text { of nanoemulsion was } \\
\text { achieved. }\end{array}$ \\
\hline $\begin{array}{l}\text { Coconut oil } \\
{[114]}\end{array}$ & $\begin{array}{c}\text { Homogenised at } \\
\text { 10,800 rpm for } 5 \\
\text { minutes. }\end{array}$ & $\begin{array}{l}5 \% \text { polyethylene } \\
\text { glycol } \\
\text { hydrogenated } \\
\text { castor oil }\end{array}$ & - & - & 162 & $\begin{array}{lrr}\text { Good stability } & \text { and } \\
\text { uniform size } & \text { of } \\
\text { nanoemulsion } & \end{array}$ \\
\hline VCO [1 15] & $\begin{array}{c}\text { homogenization at } \\
\text { 15,000 rpm for } 4 \\
\text { minutes. }\end{array}$ & $\begin{array}{c}\text { 0.5-1\% Tween } 80 \\
\text { / Span } 80 \\
\text { vco/water ratio } \\
80 / 20\end{array}$ & 8.58 & - & - & $\begin{array}{l}\text { Good oxidative stability } \\
\text { of emulsion }\end{array}$ \\
\hline $\begin{array}{l}\text { Rice bran oi } \\
\text { I[116] }\end{array}$ & $\begin{array}{c}\text { Mechanical } \\
\text { homogenising at } \\
12000 \text { rpm for } 3 \\
\text { minutes followed by } \\
\text { high-pressure } \\
\text { homogenising (HPH) } \\
\text { at } 1000 \text { MPa for } 3 \\
\text { cycles. }\end{array}$ & $\begin{array}{l}0.5-1.5 \% \text { high } \\
\text { methoxy pectin- } \\
\text { zein, } 20 \% \text { rice } \\
\text { bran oil }\end{array}$ & - & - & $\begin{array}{l}5000-6000 \\
\text { using } \\
\text { mechanical } \\
\text { homogenizer } \\
\text { and 3000- } \\
4000 \text { using } \\
\text { HPH }\end{array}$ & $\begin{array}{l}\text { Differences in } \\
\text { homogeniser pressure } \\
\text { were relatively not } \\
\text { significant compared to } \\
\text { rice bran oil } \\
\text { concentration due to the } \\
\text { high concentration of } \\
\text { rice bran oil in the } \\
\text { formulation. A good } \\
\text { physical stability of } \\
\text { emulsion was achieved. }\end{array}$ \\
\hline $\begin{array}{l}\text { Mixture of } \\
\text { sunflower and } \\
\text { olive oils [117] }\end{array}$ & $\begin{array}{l}\text { Pre-mixed at } 5000 \mathrm{rpm} \\
\text { for } 5 \text { minutes using } \\
\text { colloid mill }(\mathrm{CM} \text {, } \\
\text { followed by } \\
\text { conventional HPH at } \\
15 \mathrm{MPa} \text { or ultra-HPH at } \\
200-300 \mathrm{MPa}\end{array}$ & $\begin{array}{c}5 \% \text { sodium } \\
\text { caseinate with } \\
\text { mixture (75\% } \\
\text { sunflower oil, } 25 \% \\
\text { olive oil) }\end{array}$ & - & - & $\begin{array}{c}5421-6820 \\
\text { (CM). 98-210 } \\
\text { (ultra-HPH), } \\
\text { and 572-597 } \\
\text { (conventional } \\
\text { HPH). }\end{array}$ & $\begin{array}{l}\text { Better physical and } \\
\text { oxidative stability in ultra- } \\
\text { HPH compared to only } \\
\text { colloid milling or colloid- } \\
\text { milling with conventional } \\
\text { HPH. }\end{array}$ \\
\hline $\begin{array}{l}\text { Soy protein } \\
\text { isolate(SPI) } \\
{[118]}\end{array}$ & $\begin{array}{c}\text { HPH-homogenizing at } \\
5-80 \mathrm{MPa}\end{array}$ & $\begin{array}{l}50 \% \text { soy protein } \\
\text { isolate, } 50 \% \\
\text { soybean oil }\end{array}$ & - & - & - & $\begin{array}{l}\text { More stable SPI gels were } \\
\text { formed at higher } \\
\text { pressure, which is desired } \\
\text { to reduce the interfacial } \\
\text { tension. }\end{array}$ \\
\hline $\begin{array}{l}\text { Mussel } \\
\text { myofibrillar } \\
\text { proteins (MMP) } \\
\text { and lecithin } \\
{[119]}\end{array}$ & $\begin{array}{l}\text { Prehomogenized at } \\
20000 \text { rpm for } 2 \\
\text { minutes, } \mathrm{HPH}- \\
\text { homogenizing at } 40 \text { - } \\
120 \mathrm{MPa} \text { for } 3 \text { cycles }\end{array}$ & $\begin{array}{lr}90 \% \text { consist of soy } \\
\text { lecithin } & \text { and } \\
\text { MMP, } & 10 \% \\
\text { soybean oil } & \end{array}$ & - & 10.7-37.0 & $440-460$ & $\begin{array}{l}\text { The highest stability and } \\
\text { best emulsifying activity } \\
\text { were at } 80 \mathrm{MPa} \text {. }\end{array}$ \\
\hline
\end{tabular}




\subsection{Spray Drying Condition}

The mechanism of spray drying is designed to remove moisture through a heated condition during feeding. The process involved atomisation, a transformation of droplets into particles, and the collection of the particles [120]. For example, the inlet temperature is vital to achieving good encapsulation efficiency. Increased inlet drying temperature and inlet flow rate reduced the moisture content of the encapsulated materials. This phenomenon occurred due to the higher heat and mass transfer of the inlet air, causing a higher evaporation rate of the particles [103]. The inlet temperature should be more than $140^{\circ} \mathrm{C}$ to obtain a good encapsulation [100]. Additionally, the maximum amount of $4 \%$ of moisture content is recommended for dried powder in the food industry [121].

The moisture of $3.19 \%$ exhibited good oxidative stability in the microencapsulation of spray-dried sesame oil [122]. The inlet temperature of $180^{\circ} \mathrm{C}$, outlet temperature of $85^{\circ} \mathrm{C}$, and the feed flow rate of 10 $\mathrm{mL} / \mathrm{min}$ were used during the encapsulation of $\mathrm{VCO}$, resulting in $2.54 \%$ of moisture content [81]. The results indicated that the parameters are substantial and adequate to produce a good VCO powder. In comparison, the treatment with $170-220^{\circ} \mathrm{C}$ inlet temperatures throughout the encapsulation of babassu coconut milk achieved moisture contents of 10.53$2.39 \%$ [102]. However, if the inlet temperature is too low, water evaporation becomes inefficient, resulting in wet powder and low encapsulation yield [123]. The higher moisture of $5.74 \%$ was achieved by oven drying at $50^{\circ} \mathrm{C}$ to produce coconut milk powder [124]. Additionally, the moisture content also impacted the powder's flowability, as the moisture content of $4 \%$ was required to produce a good flow characteristic of the coconut flour [125].

\subsection{Powder Collection}

In a spray dryer, the coarse dry particles are collected in the chamber attached to the spray dryer [120]. The remaining finer particles (less than 30\%) are further conveyed to the cyclone separator or bag filter attached to the spray dryer. The cyclone separator more opts since it offers higher efficiency for powder entrapment [127].

Once the powder is collected, it must be kept under proper packaging to maintain its quality and prolong its shelf life. For instance, infant milk powder can easily oxidise, caking and browning is suitable to be packed with poly-olefin metal containers. It is better to purge the container with nitrogen or carbon dioxide gas to remove the remaining oxygen. Another method introduced is to use high gas resistant packaging, such as composite paper cans and flexible pouches. For any of these methods, it is best to keep the product under room temperature [128]. Meanwhile, the moisture content of coconut protein powder did not show a significant effect when stored at $4-38^{\circ} \mathrm{C}$ using metal polyester packaging. It exhibited that the polyester packaging can prevent oxygen, light and moisture from penetrating inside the packaging [129]. Overall, it is better to keep the coconut powder at a lower temperature and under nitrogen gas treatment to avoid product deterioration [130].

\subsection{Characterisation of Microencapsulated VCO}

The characteristics that determine the quality of microencapsulated oil are solubility, bulk density, wettability, and other indicative measurements as required by a study. For VCO, the microencapsulation process's ability to preserve the minor compound and provide oxidative stability is essential to ensure the powdered VCO has a similar quality characteristic as in liquid form. During microencapsulation VCO using spray drying and $\mathrm{SC}-\mathrm{CO}_{2}$, both methods demonstrated the ability to preserve phenolic compounds and antioxidant in VCO. The spray drying and supercritical carbon dioxide (SC-CO ) methods successfully retained the maximum of 1.13 (mmol $\mathrm{BHT} / \mathrm{ml}$ oil) of phenolic content. However the $\mathrm{SC}-\mathrm{CO}_{2}$ achieved higher antioxidant capacity of (0.8-1.48 (mmol Trolox/ml oil) compared to spray drying method of 1.48 (mmol Trolox/ml) [81], [82]. Meanwhile, the peroxide value of VCO powder achieved was also relatively within the limit of Malaysia Standards of below $3 \mathrm{meq} / \mathrm{kg}$ oil in the spray-drying method [81]. Comparatively, the $\mathrm{SC}-\mathrm{CO}_{2}$ system exhibited a better quality of the powder produced, but the equipment is more expensive than the spray dryer. Besides, spray-drying is more economical, versatile, and already proven in the food industry [123].

A spray-dryer application creates a layer of fat on its particle surface that can reduce its solubility and increase oxidation and stickiness, which degrades the product's quality. High powder solubility is required to ensure optimum functionality in the food system [78]. For instance, solubility lower than $65 \%$ was achieved using a spray dryer compared to a freeze-drying method that reached $80 \%$ solubility during coconut skim milk encapsulation. The variation in the powder's solubility was also shown in the different concentration of emulsion [126]. By using different concentrations of sodium caseinate and type of protein source, the different solubility was achieved in the freeze-dried creamer [127]. Other reports indicated the solubility difference from slightly soluble to very soluble resulting from different maltodextrin concentrations and skim milk during coconut powder encapsulation [128]. However, spray drying provided a better sensory effect but retained its moderately good functional properties compared to freeze-drying [126].

The characteristic of powdered oil, such as its high bulk density, significantly impacts the functional and economic assessment as it reduces the packaging and transportation costs [129]. Low bulk density is undesirable due to its positive correlation with oxidation and its stability [102]. The bulk density increased significantly by lowering the inlet drying temperature, and the aspiration rate from the outer layer of the droplet is rapidly dried. Higher bulk density can also be achieved by increasing the feed mass flow rate. 
Inversely, the minimised drying temperature and increased feed flow rate reduce the powder's size and the encapsulation efficiency with a higher moisture content [130]. The $350 \mathrm{~kg} / \mathrm{m}^{3}$ bulk density of coconut protein powders was reported when the inlet temperature was $130^{\circ} \mathrm{C}$ and a flow rate of $75 \mathrm{ml} / \mathrm{min}$ [131]. Meanwhile, a bulk density of $850 \mathrm{~kg} / \mathrm{m}^{3}$ was obtained when the inlet temperature was $160^{\circ} \mathrm{C}$ during Black seed oil encapsulation [132].

The low concentration of wall material also reduced the bulk density but adversely affected the spray-dried powder's particle density [133]. Various bulk densities (550-620 kg/m ${ }^{3}$ ) were shown when using different concentrations of sodium caseinate in the emulsion during the production of non-dairy creamer [127]. All these results suggested that adjustments in formulation and drying conditions would lead to variation in bulk density.

The interaction between bulk powder with water can be thermodynamically determined by wettability\{Formatting Citation\}. The dispersibility shows the quickness of the powder to dispersed in water through slow stirring [131]. Wettability is generally influenced by the size, size distribution, and particle shape of the powder [134]. The type of wall materials and the amount of total soluble solid used in the formulation also improved powder wettability. It noted that the wettability of $30-60 \mathrm{~s}$ is required to ensure a good dispersibility of the powder in the water [102], [135]. The wettability of $60 \mathrm{~s}$ with a dispersibility of $93 \%$ was achieved during microencapsulation of coconut skim milk powder. The particle size was $70 \mu \mathrm{m}$ with irregular shapes and had no crack [131]. However, in coconut milk whey encapsulation, the wettability of (21-23s) with dispersibility (93-97\%) was achieved. The particle size of $69.5-78.8 \mu \mathrm{m}$ with no indication of the particle shape was reported [135]. Both studies indicated relatively similar particle sizes but differed in wettability. This divergence may be caused by the difference in spray drying processing parameters, affecting the final moisture content, wettability, and hygroscopicity of the powder [105]. By using different types of wall material, the whey protein isolates exhibited the highest wettability powder (420s), compared to the use of the mixture of whey protein isolate/maltodextrin (265s) and whey protein isolate/inulin (205s) during the encapsulation of novel structure lipids. The low wettability indicated that the particles are easily in contact with water, showing the ability to wet well. The whey protein isolate/inulin also had the lowest free oil value to reduce hydrophobicity and minimise particle surface blockage in contact with water [121].

\subsection{CONCLUSION}

This overview reveals the benefit of VCO and the process involved during the extraction and microencapsulation of the oil. Copra oil practically produces a high oil recovery, but it undergoes the RBD process, consequently eliminating some of the essential nutrients present in the coconut oil. Therefore, to alleviate this issue, several other attempts were studied to produce VCO without compromising its quality. Generally, all the methods had shown an adequate MCFA oil supply but differ in terms of the fatty acid concentration due to variation in raw material preparation, processing conditions, and methods used.

The evolution of VCO has been extended to the microencapsulation of its oil for better handling and storage capacity. The preparation of the emulsion and the processing parameters of the equipment must be considered to produce good quality microencapsulated VCO. The spray dryer's processing condition also contributes to the excellent quality of vCO powder, such as inlet temperature and flow rate.

\section{Acknowledgement}

The authors would like to thank all members of the Institute of Bioproduct Development (IBD), UTMLEAD and Grant Q.J130000.2851.00L39 for the encouragement and support.

\section{References}

[1] Bawalan, K. R, Chapman and D. D. 2006. Virgin Coconut Oil: Production Manual for Micro- and Village-Scale Processing. FAO Regional Office for Asian and the Pacific. http://www.fao.org/3/a-bt726e.pdf (accessed Jan. 14, 2019).

[2] Global Coconut Water Market and Coconut Oil Market 2018 By Demand, Consumption, Production, Top Regions, Key Manufacturers, Growth \& Forecast Till 2023. Orbis Research, 2018. https://www.reuters.com/brandfeatures/venturecapital/article?id=38929 (accessed Jul. 03, 2019).

[3] Dayrit, F. M. 2014. Lauric Acid is a Medium-Chain Fatty Acid, Coconut Oil is a Medium-Chain Triglyceride. Philippine Journal of Science. 143(2): 157-166.

[4] Kapally, S.; Shirwaikar, A; and Shirwaikair, A. 2015. A Review of Potential Applications. Hygeia Journal for Drug and Medicine. 7(2): 34-41. DOI: 10.15254/H.J.D.Med.7.2015.149.

[5] PNS/BAFPS 22:2004. 2004. Philippine National Standard: Virgin coconut oil (VCO). Bureau of Products Standards, Department of Trade and Industry, Makati City, Philippine. ppl-8.

[6] Quality Standards Virgin Coconut Oil. 2009. Asian Pacific Coconut Community (APCC). Indonesia. 1-2.

[7] Osman, A. 2019. Fruit Oils: Chemical and Functionality. DOI: 10.1007/978-3-030-12473-1.

[8] Poshadri, A., and Kuna, A. 2010. Microencapsulation Technology: A Review. The Journal of Research ANGRAU. 38(1): 86-102.

[9] Bakry, A. M., Abbas, S, Ali, B. Majeed, H., Abouwelwafa, M. Y., Mousa, A., and Liang, L. 2016. Microencapsulation of Oils: A Comprehensive Review of Benefits, Techniques, and Applications. Comprehensive Reviews in Food Science and Food Safety. 15(1): 143-182. DOI: 10.1111/1541-4337.12179.

[10] Nedovic, V. , Kalusevic, A., Manojlovic, V., Levic, S., and B. Bugarski. 2011. An Overview of Encapsulation Technologies for Food Applications. Procedia Food Science. 1: 806-1815. DOI: 10.1016/j.profoo.2011.09.265.

[11] Desai, N. M., Haware, D. J., Basavaraj, K., and Murthy, P. S. 2019. Microencapsulation of Antioxidant Phenolic Compounds from Green Coffee. Preparative Biochemistry and Biotechnology. 49(4): 400-406. DOI: 
$10.1080 / 10826068.2019 .1575858$.

[12] Turchiuli, C., Lemarié, N., Cuvelier, M. E., and Dumoulin, E. 2013. Production of Fine Emulsions at Pilot Scale for Oil Compounds Encapsulation. Journal of Food Engineering. 115(4): 452-458. DOI: 10.1016/j.jfoodeng.2012.02.039.

[13] Jafari, S. M., Assadpoor, E., He, Y., and Bhandari, B. 2008. Encapsulation Efficiency of Food Flavours and Oils During Spray Drying. Drying Technology. 26(7): 816-835. DOI: 10.1080/07373930802135972.

[14] Zhou, D., Pan, Y., Ye, J., Jia, J., Ma, J., and Ge, F. 2017. Preparation of Walnut Oil Microcapsules Employing Soybean Protein Isolate and Maltodextrin with Enhanced Oxidation Stability of Walnut Oil. LWT - Food Science and Technology 83: 292-297. DOI: 10.1016/j.Iwt.2017.05.029.

[15] Li, J., Xiong, S., Wang, F., Regenstein, J. M., and Liu, R. 2015. Optimisation of Microencapsulation of Fish Oil with Gum Arabic/Casein/Beta-Cyclodextrin Mixtures by Spray Drying. Journal of Food Science. 80(7): 1445-1452. DOI: 10.1111 1/17503841.12928.

[16] DebMandal, M., and Mandal, S. 2011. Coconut (Cocos nucifera L.: Arecaceae): In Health Promotion and Disease Prevention. Asian Pacific Journal of Tropical Medicine. 4(3): 241-247. DOI: 10.1016/S1995-7645(11)60078-3.

[17] Marina, A. M., Che Man, Y. B., Nazimah, S. A. H., and Amin, I. 2009. Chemical Properties of Virgin Coconut Oil. Journal of the American Oil Chemists's Society. 86(4): 301-307. DOl: 10.1007/s1 1746-009-1351-1.

[18] Gunstone, F. D. 2011. Production and Trade of Vegetable Oils. 2nd ed. Boca Raton: CRC Press.

[19] Nevin, K. G., and Rajamohan, T. 2006. Virgin Coconut Oil Supplemented Diet Increases the Antioxidant Status in Rats. Food Chemistry. 99(2): 260-266. DOI: 10.1016/j.foodchem.2005.06.056.

[20] Arlee, R., Suanphairoch, S., and Pakdeechanuan, P. 2013. Differences in Chemical Components and AntioxidantRelated Substances in Virgin Coconut Oil from Coconut Hybrids and Their Parents. International Food Research Journal. 20(5): 2103-2109.

[21] Andersson, S. C., Ekholm, A., Johansson, E., Olsson M.E., Sjöholm, I., Nyberg, L., Nilsson, A., and Rumpunen, K. 2015 Effect of Storage Time and Temperature on Stability of Bioactive Compounds in Aseptically Packed Beverages Prepared from Rose Hips and Sea Buckthorn Berries. Agricultural and Food Science. 24(4): 273-288. DOl: 10.23986/afsci.49331.

[22] Raghavendra, S. N., and Raghavarao, K. S. M. S. 2011. 2011. Aqueous Extraction and Enzymatic Destabilization of Coconut Milk Emulsions. Journal of American Oil Chemists' Society. 88(4): 481-487. DOI: 10.1007/s1 1746-010-1695-6.

[23] Krebs, T., Schroën, C. G. P. H., and Boom, R. M. 2012. Separation Kinetics of an Oil-in-Water Emulsion Under Enhanced Gravity. Chemical Engineering Science. 71: 118125. DOI: 10.1016/j.ces.2011.10.057.

[24] Rousseau, D., Ghosh, S., and Park, H. 2009. Comparison of the Dispersed Phase Coalescence Mechanisms in Different Tablespreads. Journal of Food Science. 74(1): 1-7. DOI:10.1111/j.1750-3841.2008.00978.x.

[25] Marina, A. M., Che Man, Y. B., and Amin, I. 2009. Virgin coconut oil: Emerging Functional Food Oil. Trends in Food Science \& Technology. 20(10): 481-487. DOI: 10.1016/j.tifs.2009.06.003

[26] Tangsuphoom, N., and Coupland, J. N. 2009. Effect of Thermal Treatments on the Properties of Coconut Milk Emulsions Prepared with Surface-active Stabilizers. Food Hydrocolloids. 23(7): 1792-1800. DOl: 10.1016/j.foodhyd.2008.12.001.

[27] Boode, K., Walstra, P., and de Groot-Mostert, A. E. A.1993. Partial Coalescence in Oil-in-Water Emulsions 2. Influence of the Properties of the Fat. Colloids and Surfaces: A Physicochemical and Engineering Aspects. 81: 139-151. DOl: 10.1016/0927-7757(93)80240-F.

[28] Agarwal, R. K. 2017. Extraction Processes of Virgin Coconut Oil. MOJ Food Processing and Technology. 4(2): 2-4. DOI: 10.15406/mojfpt.2017.04.00087.
[29] Walstra, P. 2005. 'Emulsions'. In: Lyklema, J. (Ed.). Fundamentals of Interface and Colloids Science. $1^{\text {st }}$ ed. (vol 5). Waginingen, The Netherlands : Elsevier Ltd.

[30] Seow, C. C., and Gwee, C. N. 1997. Coconut Milk: Chemistry and Technology. International Journal of Food Science and Technology. 32(3): 189-201. DOI: 10.1046/j.13652621.1997.00400.x.

[31] Hamid, M. A., Sarmidi, M. R., Mokhtar, T. H., Sulaiman, W. R. W., and Aziz, R.A. 2011 . Innovative integrated Wet Process for Virgin Coconut Oil Production. Journal of Applied Science. 11 (13): 2467-2469. DOI: 10.3923/jas.201 1.2467.2469.

[32] Gunetileke, K. G., and Laurentius, S. F. 1974. Conditions for the Separation of Oil and Protein from Coconut Milk Emulsion. Journal of Food Science. 39(2): 230-233. DOI: 10.1111/j.13652621.1974.tb02863.x

[33] Rosenthal, A., Pyle, D. L., and Niranjan, K. 1996. Aqueous and Enzymatic Processes for Edible Oil Extraction. Enzyme and Microbial Technology. 19(6): 402-420. DOI: 10.1016/S0141$0229(96) 80004-\mathrm{F}$.

[34] Shamsul Anuar, N. A. 2012. Lipids and Phytochemicals Profiles of Non Heat Treated Virgin Coconut Oil. Universiti Teknologi Malaysia.

[35] Che Man, Y. B., Abdul Karim, M. I. B., and Teng, C. T. 1997. Extraction of Coconut Oil with Lactobacillus plantarum 1041 IAM. Journal of American Oil Chemists' Society. 74(9): 1115 1119. DOI: 10.1007/s1 1746-997-0033-0.

[36] Asmoro, N., Widyastuti, R., and Junius Ndrudu, J. Production of Virgin Coconut Oil (VCO) using Fermentation Method Extraction with Ragi Tempe. 2018. Advances in Engineering Research. 175: 74-77. DOI: 10.2991/icase-18.2018.20.

[37] Masyithah, Z. 2017.Parametric Study in Production of Virgin Coconut Oil by Fermentation Method. Oriental Journal of Chemistry. 33(6): 3069-3076. DOI: 10.13005/ojc/330647.

[38] Jasman, Gabur, R. M. P., Lede, N. M., Lota, C. N., Nubatonus, R. A., Sudirman, and Lawa, Y. 2019. Evaluation of Some Factors Affecting Yield and Quality of Virgin Coconut Oil (VCO) Produced by Fermentation using Baker Yeast. Ecology Environment and Conservation. 25: S23-S30.

[39] Sant'Anna, B. P. M., Freitas, S. P., and Coelho, M. A. Z. 2003. Enzymatic Aqueous Technology for Simultaneous Coconut Protein and Oil Extraction. Grasas y Aceites. 54(1): 77-80. DOI: 10.3989/gya.2003.v54.i1.281.

[40] Nurah, T. O., WMADB, F., Ranil, C., Isona, G., and Vijay, J. 2017. Effect of Extraction Techniques on the Quality of Coconut Oil. African Journal of Food Science. 11 (3): 58-66. DOI: 10.5897/ajfs2016.1493.

[41] Che Man, Y. B., Asbi, A., Azudin, M. N., and Wei, L. S.1996. Aqueous Enzymatic Extraction of Coconut Oil. Journal of American Oil Chemists' Society. 73( 6): 683-686. DOI: 10.1007/BF02517940.

[42] Xiao, J., Li, Y., George, O. Y., Li, Z., Yang, S., Woo, M., W., Woo, W. D., and Chen, X. D. 2018. Numerical Investigation of Droplet Pre-Dispersion in a Monodisperse Droplet Spray Dryer. Particuology. 38: 44-60. DOI: 10.1016/j.partic.2017.04.008.

[43] de Moura e Dias, M., Siqueira, N. P., Conceição,L., L., d., dos Reis, S. A., Valente, F. X., Dias, M.M. d., S., Rosa, C., d., O., B. Paula, S. O.,d., Matta S., L., P., d., Oliveira, L., L., d., Bressen, J., and Peluzio, M., d., C., G. 2018. Consumption of Virgin Coconut Oil in Wistar Rats Increases Saturated Fatty Acids in the Liver and Adipose Tissue, as well as Adipose Tissue Inflammation. Journal of Functional Foods. 48: 472-480. DOI: 10.1016/j.jff.2018.07.036.

[44] Bach, A. C., and Babayan, K. 1982. Medium-chain Triglycerides: An Update. The American Journal of Clinical Nutrition. 36: 950-962.

[45] Babayan, V. K. 1968. Medium-chain Triglycerides-Their Composition, Preparation, and Application. Journal of American Oil Chemists' Society. 45(1): 23-25. DOl: 10.1007/BF02679040.

[46] Hu, F. B. Stampfer, M. J., Manson, J. E., Ascherio, S., Colditz, Manson, J. E., Ascherio, A., Colditz., G. A., Speizer., F. E., Hennekens, C. H., and Willett, W. C. 1999. Dietary Saturated Fats and Their Food Sources in Relation to The Risk Of Coronary Heart Disease in Women. American Journal of 
Clinical Nutrition. 70(6): 1001-1008

[47] Traul, K. A. , Driedger, A., Ingle, D. L., and Nakhasi, D. 2000 Review of the Toxicologic Properties of Medium-chain Triglycerides. Food and Chemical Toxicology. 38(1): 79-98. DOI:10.1016/S0278-6915(99)00106-4.

[48] Oh, K., Hu, F. B., Manson, J. E., Stampfer, M. J., and Willett, W. C. 2005. Dietary Fat Intake and Risk of Coronary Heart Disease in Women: 20 Years of Follow-up of The Nurses' Health Study. The American Journal of Epidemiology. 161(7): 672 679 DOI: 10.1093/aje/kwi085.

[49] Kaunitz, H. 1986. Medium Chain Triglycerides (MCT) in Aging and Arteriosclerosis. Journal of Environmental Pathology, Toxicology and Oncology. 6: 115-121.

[50] Decuypere, J. A., and. Dierick, N. A. 2003. The Combined Use of Triacylglycerols Containing Medium-chain Fatty Acids and Exogenous Lipolytic Enzymes as an Alternative to In-feed Antibiotics in Piglets: Concept, Possibilities and Limitations. An overview. Nutrition Research Review. 16(2): 193-210. DOI: $10.1079 / \mathrm{nrr} 200369$

[51] Salentinig, S., Yepuri, N. R., Hawley, A., Boyd, B. J., Gilbert, E., and Darwish, T. A. 2015. Selective Deuteration for Molecular Insights Into the Digestion of Medium Chain Triglycerides. Chemistry and Physic of Lipids. 190: 43-50. DOI: 10.1016/j.chemphyslip.2015.06.007.

[52] Schönfeld, P., and Wojtczak, L. 2016. Short- and Mediumchain Fatty Acids in Energy Metabolism: The Cellular Perspective. The Journal of Lipid Research. 57(6): 943-954. DOI: 10.1194/jlr.R067629.

[53] Kumar, P. K. P., and Krishna, A. G. G. 2015. Physicochemical Characteristics of Commercial Coconut Oils Produced in India. Grasas y Aceites. DOI: 10.3989/gya.0228141.

[54] Laureles, L. R., Rodriguez, F. M., Reaño, C. E. , Santos, G. A., Laurena, A. C., and Mendoza, E. M. T. 2002. Variability in Fatty Acid and Triacylglycerol Composition of the Oil of Coconut (Cocos nucifera L.) Hybrids and Their Parentals. Journal of Agricultural and Food Chemistry. 50(6): 1581-1586. DOl: $10.1021 / \mathrm{jf0} 10832 \mathrm{w}$.

[55] Arumuganathan, T. 2011. Lipid Profile of Virgin Coconut Oil Processed. Journal of Plant Breeding and Crop Science. 39(1): 247-251.

[56] Mansor, T. S. T., Che Man, Y., Shuhaimi, M., Abdul Afiq, M. J., and, Ku Nurul. 2012. Physicochemical Properties of Virgin Coconut Oil Extracted from Different Processing Methods. International Food Research Journal. 19(3): 837-845.

[57] Derawi, D. , Azman, N. A. Z., and Jumadi, M. F. 2017. Kajian awal Penghasilan monoasilgliserol dan Diasilgliserol Minyak Kelapa Dara Melalui Gliserolisis Berenzim Menggunakan lipase Candida Antarctica (Novozyme 435). The Malaysian Journal of Analytical Science. 21(1): 37-45. DOl: 10.17576/mjas-2017-2101-05.

[58] Santesh, N., and Prasad, N. B. L. 2012. Production of Virgin Coconut Oil from Dry and Wet Methods of Induced Fermentation and Its Characterisation. European Journal of Lipid Science and Technology. 44(2): 47-53.

[59] Arumuganathan, T. 2014. Lipid Profile of Virgin Coconut Oil Processed. Journal of Plant Breeding and Crop Science. 39(1): 247-251.

[60] Ahmad, Z., Hasham, R., Aman Nor, N. F., and Sarmidi, M. R. 2015. Physico-chemical and Antioxidant Analysis of Virgin Coconut Oil Using West African Tall Variety. Journal of Advance Research in Material Science. 13(1): 2289-7992.

[61] Marina, M., Wan Rosli, W. M., and Noorhidayah, A. M. 2014. Quantitative Analysis of Peroxide Value in Virgin Coconut Oil by ATRFTIR Spectroscopy. The Open Conference Proceeding Journal. 4(1): 53-56. DOI: 10.2174/2210289201304020053.

[62] Faulds, C. B., Bartolomé, B., and Williamson, G. 1997. Novel Biotransformations of Agro-Industrial Cereal Waste by Ferulic Acid Esterases. Industrial. Crops and Products. 6(3-4): 367-374. DOI: 10.1016/S0926-6690(97)00027-7.

[63] Dey, G., Chakraborty, M., and Mitra, A. 2005. Profiling C6-C3 and $\mathrm{C} 6-\mathrm{Cl}$ Phenolic Metabolites in Cocos nucifera. Journal of Plant Physiology. 162(4): 375-381. DOI: 10.1016/j.jplph.2004.08.006.

[64] Neo, Y. P., Ariffin, A., Tan, C. P., and Tan, Y. A. 2010. Phenolic
Acid Analysis and Antioxidant Activity Assessment of Oil Palm (E. guineensis) Fruit Extracts. Food Chemistry. 122(1): 353-359. DOI: 10.1016/j.foodchem.2010.02.046.

[65] Tüzen, M., and Özdemir, M. 2003. Chromatographic Determination of Phenolic Acids in The Snowdrop by HPLC. Turkish Journal of Chemistry. 27(1): 49-54.

[66] Seneviratne, K. N., Hapuarachchl, C. D., and Ekanayake, S. 2009. Comparison of the Phenolic-Dependent Antioxidant Properties of Coconut Oil Extracted Under Cold and Hot Conditions. Food Chemistry. 114(4): 1444-1449. DOI: 10.1016/j.foodchem.2008.11.038.

[67] Gutfinger, T. 1981. Polyphenols in Olive Oils. Journal of the American Oil Chemists' Society. 58(11): 966-968. DOI: 10.1007/BF02659771.

[68] Chun, J., Lee, J., Ye, L., Exler, J., and Eitenmiller, R. R. 2006. Tocopherol and Tocotrienol Contents of Raw and Processed Fruits and Vegetables in the United States Diet. Journal of Food Composition and Anaysis. 19(2-3): 196-204. DOI: 10.1016/j.jfca.2005.08.001.

[69] Alajtal, A. I, Sherami, F. E., and Elbagermi, M. A. 2018. Acid, Peroxide, Ester and Saponification Values for Some Vegetable Oils Before Acid, Peroxide, Ester and Saponification Values for Some Vegetable Oils Before and After Frying. American Association for Science and Technology. 4(2): 43-47.

[70] Virgin Coconut Oil-Specification. 2007. Department of Standards Malaysia, Minstry of Science, Technology and Innovation, Malaysia.1-6.

[71] Dayrit, F. M., Buenafe, O. E. M., Chainani, E. T., and Vera, I. M. S. d. 2007. Standards for Essential Composition and Quality Factors of Commercial Virgin Coconut Oil and Its Differentiation from RBD Coconut Oil and Copra Oil. Philippine Journal of Science. 136(2): 119-129.

[72] Odoom, W., and Edusei, V. O. 2015. Evaluation of Saponification Value, lodine Value and Insoluble Impurities in Coconut Oils From Jomoro District in the Western Région of Ghana. Asian Journal of Agricultural and Food Science. 3(5): 2321-1571.

[73] Prapun, R., Cheetangdee, N., and Udomrati, S. 2016. Characterisation of Virgin Coconut Oil (VCO) Recovered by Different Techniques and Fruit Maturities. International Food Research Journal. 23(5): 2117-2124.

[74] Rini Handayani, R. D. R., and Joko Sulistyo. 2009. Extraction of Coconut Oil (Cocos nucifera L.) through Fermentation System. Biodiversitas, Journal of Biological Diversity. 10(3): 151-157. DOI: 10.13057/biodiv/d100309.

[75] Rohyami, Y., Anjani, R. D., and Purwanti, N. P. 2017. The Influence of Saccharomyces Cerevisiae Enzyme Ratio on Preparation Virgin Coconut Oil for Candidate In-house Reference Materials. AIP Conference Proceeding 1823. DOI: $10.1063 / 1.4978159$

[76] Mahesar, S. A., Sherazi, S. T. H. , Khaskheli, A. R., Kandhro, A. A., and Uddin, S. 2014. Analytical Approaches for the Assessment of Free Fatty Acids in Oils and Fats. Analytical Methods. 6(14): 4956-4963. DOI: 10.1039/c4ay00344f.

[77] Wilson, N., and Shah, N. P. 2007. Microencapsulation of Vitamins. International Food Research Journal. 14(1): 1-14.

[78] Foerster, M., Liu, C., Gengenbach, T., Woo, M. W., and Selomulya, C. 2017. Reduction of Surface Fat Formation on Spray-dried Milk Powders Through Emulsion Stabilization with $\lambda$-carrageenan. Food Hydrocolloids. 70: 163-180. DOI: 10.1016/j.foodhyd.2017.04.005

[79] Ray, S., Raychaudhuri, U., and Chakraborty, R. 2016. An overview of Encapsulation of Active Compounds Used in Food Products by Drying Technology. Food Bioscience. 13: 76-83. DOI: 10.1016/j.fbio.2015.12.009.

[80] Xie, Y. L., Zhou, H. M., Liang, X. H., He, B. S., and Han, X. X. 2010. Study on the Morphology, Particle Size and Thermal Properties of Vitamin A Microencapsulated by Starch Octenylsucciniate. Agricultural Science in China. 9(7): 10581064. DOI: 10.1016/S1671-2927(09)60190-5.

[81] Hee, Y. Y., Tan, C. P., Abdul Rahman, R., Mohd Adzahan, N. Lai, W. T., and Chong G. H. 2015. Influence of Different Wall Materials on the Microencapsulation of Virgin Coconut Oil by 
Spray Drying. International Journal of Food Engineering. 11 (1): 61-69. DOI: 10.1515/ijfe-2014-0215.

[82] Hee, Y. Y., Tan, C. P., Rahman, R. A., Noranizan, M., Smith, R. L., and Chong, G. H. 2017. Production of Virgin Coconut Oil Microcapsules from Oil-in-Water Emulsion with Supercritical Carbon Dioxide Spray Drying. Journal of Supercriical Fluids.130: 18-124. DOI: 10.1016/j.supflu.2017.07.037.

[83] Huang, Y., Deng, S., Chen, W., Xia, Q., Li, R., and Zhao, S. 2011. Optimisation of Technology for Virgin Coconut Oil Microencapsulation by Response Surface Methodology. Advanced Material Research. 308-310: 1627-1635. DOI: 10.4028/www.scientific.net/AMR.308-310.1627.

[84] Quispe, N. B. P., Chaves, M. A., Santos, A. F., Bastos, T. D. S., and Castro, S. S. 2020. Microencapsulation of Virgin Coconut Oil by Spray Drying. Brazilian Journal of Development. 6(1): 1510-1529. DOI: 10.34117/bjdv6n1-103.

[85] Fang, Z., and Bhandari, B. 2010, Encapsulation of Polyphenols -A Review. Trends in Food Science \& Technology. 21 (10): 510523. DOI: 10.1016/j.tifs.2010.08.003.

[86] Mozafari, M. R., Khosravi-Darani, K., Borazan, G. G., Cui, J., Pardakhty, A., and Yurdugul, S. 2008. Encapsulation of Food Ingredients Using Nanoliposome Technology. International Journal of Food Properties. 11(4): 833-844. DOl: 10.1080/10942910701648115.

[87] Premi, M., and Sharma, H. K. 2017. Effect of Different Combinations of Maltodextrin, Gum Arabic and Whey Protein Concentrate on the Encapsulation Behavior and Oxidative Stability of Spray Dried Drumstick (Moringa oleifera) Oil. International Journal of Biological Macromolecule. 105: 1232-1240 DOI: 10.1016/j.ijbiomac.2017.07.160.

[88] Hernandez Sanchez, M. D. R., Cuvelier, M. E., and Turchiuli, C. 2015. Design of Liquid Emulsions to Structure Spray Dried Particles. Journal of Food Engineering. 167: 99-105. DOl: 10.1016/j.jfoodeng.2015.07.036.

[89] Wisniewski, R. 2015. Spray Drying Technology Review. 2015. International Conference on Environmental System. 1-9.

[90] Schramm, L. L. , Stasiuk, E. N., and Marangoni, D. G. 2003. Surfactants and Their Applications. Annual Reports on the Progress Chemistry - Sect. C. 99(2): 3-48. DOI: 10.1039/B208499F.

[91] Ibrahim, N., Raman, I. A., and Yusop, M. R. 2015. Effects of Functional Group of Non-lonic Surfactants on The Stability of Emulsion (Kesan Perbezaan Kumpulan Berfungsi Surfaktan Bukan Ionik Terhadap Kestabilan Emulsi). Malaysian Journal of Analytical Science. 19(1): 261-267.

[92] Ja'Afar, S. M., Khalid, R. M., Othaman, R., Mokhtar, W. N. A. W., and Ramli, S. 2019. Coconut oil based Microemulsion Formulations for Hair Care Product Application. Sains Malaysiana. 48(3): 599-605. DOI: 10.17576/jsm-2019-4803-12.

[93] Fatimah, F., Gugule, S., and Tallei, T. 2017. Characteristic of Coconut Milk Powder Made by Variation of Coconut-Water Ratio, Concentration of Tween and Guar Gum. Article Journal of Applied Science Research. 13(6): 34-44.

[94] Fuller, G. T., Considine, T., Golding, M., Matia-Merino, L., and MacGibbon, A. 2015. Aggregation Behavior of Partially Crystalline Oil-in-Water Emulsions: Part II - Effect of Solid Fat Content and Interfacial Film Composition on Quiescent and Shear Stability. Food Hydrocolloids. 51: 23-32. DOI: 10.1016/j.foodhyd.2015.03.032.

[95] McClements, D. J., Decker, E. A., and Weiss, J. 2007. Emulsionbased Delivery Systems for Lipophilic Bioactive Components. Journal of Food Science. 72: 8:109-124. DOI: 10.1111/j.17503841.2007.00507.x.

[96] Himmetagaoglu, A. B., Erbay, Z., and Cam, M. 2018. Production of Microencapsulated Cream: Impact of Wall Materials and Their Ratio. International Dairy Journal. 83: 2027. DOI: 10.1016/j.idairyj.2018.03.007.

[97] Turchiuli, C., Jimenez Munguia, M. T., Hernandez Sanchez, M., Cortes Ferre, H., and Dumoulin, E. 2014. Use of Different Supports for Oil Encapsulation In Powder by Spray Drying. Powder Technology. 255: 103-108. DOI: 10.1016/j.powtec.2013.08.026.

[98] E. M. Both, I. Siemons, R. M. Boom, and M. A. I. Schutyser. 2019.
The Role of Viscosity in Morphology Development During Single Droplet Drying. Food Hydrocolloids. 94: 510-518. DOI: 10.1016/j.foodhyd.2019.03.023.

[99] Both, E. M., Siemons, I. , Boom, R. M., and Schutyser, M. A. I. 2019. The Role of Viscosity in Morphology Development During Single Droplet Drying. Food Hydrocolloids. 94: 510-518. DOI: 10.1016/j.foodhyd.2019.03.023.

[100] Fioramonti, S. A., Stepanic, E. M., Tibaldo, A. M., Pavón, Y. L., and Santiago, L. G. 2019. Spray Dried Flaxseed Oil Powdered Microcapsules Obtained Using Milk Whey Proteins-Alginate Double Layer Emulsions. Food Research International Journal. 119:931-940. DOI: 10.1016/j.foodres.2018.10.079.

[101] Ramakrishnan, Y., Adzahan, N. M., Yusof, Y. A., and Muhammad, K. 2018. Effect of Wall Materials on the Spray Drying Efficiency, Powder Properties and Stability of Bioactive Compounds In Tamarillo Juice Microencapsulation. Powder Technology. 328: 406-414. DOI: 10.1016/j.powtec.2017.12.018

[102] Santana, A. A., de Oliveira, R. A., Pinedo, A. A., Kurozawa, L. E., and Park, K. J. 2013. Microencapsulation of Babassu Coconut Milk. Food Science and Technology. 33(4): 737-744. DOI: 10.1590/S0101-20612013000400020.

[103] Corrêa-Filho, L. C., Lourenço, S. C., Duarte, D. F., MoldãoMartins, M., and Alves, V. D. 2019. Microencapsulation of Tomato (solanum lycopersicum I.) Pomace Ethanolic Extract by Spray drying: Optimisation of Process Conditions. Applied Science. 9(3): 1-15. DOI: 10.3390/app9030612.

[104] Zafisah, N. S., Yusuf, Y. A., Ali, M. A., Roslan, N. S.,Tahir, A., Aziz, M. G., and Chin, N. L. 2018. Processing of Raw Coconut Milk for Its Value Addition Using Spray and Freeze Drying Techniques. Journal of Food Process Engineering. 41 (1): 1-11. DOI: $10.1111 /$ jfpe. 12602 .

[105] de B. Fernandes, R. V., Borges, S. V., and Botrel, D. A. Influence of Spray Drying Operating Conditions on Microencapsulated Rosemary Essential Oil Properties. Ciência e Tecnologia Alimentos. 2013. 33: 171-178. DOI: 10.1590/s0101-20612013000500025.

[106] Hebishy, E., Buffa, M., Guamis, B., Blasco-Moreno, A., and Trujillo, A. J. 2015. Physical and Oxidative Stability of Whey Protein Oil-in-Water Emulsions Produced by Conventional and Ultra High-pressure Homogenization: Effects of Pressure and Protein Concentration on Emulsion Characteristics. Innovative Food Science and Emerging Technology. 32: 7990. DOI: 10.1016/j.ifset.2015.09.013

[107] Anihouvi, P. P., Danthine, S., Kegelaers, Y., Dombree, A., and Blecker, C. 2013. Comparison of the Physicochemical Behavior of Model Oil-in-Water Emulsions Based on Different Lauric Vegetal Fats. Food Research International. 53(1): 156163. DOI: 10.1016/j.foodres.2013.04.011.

[108] Sanjeewani, N. A., and Sakeena, M. H. F. 2013. Formulation and Characterisation of Virgin Coconut Oil (VCO) Based Emulsion. International Journal of Scientific and Research Publications. 3(12): 1-6.

[109] Janiszewska, E., Jedlińska, A., and Witrowa-Rajchert, D. 2015 Effect of Homogenization Parameters on Selected Physical Properties of Lemon Aroma Powder. Food Bioproduct Processing. 94: 405-413. DOI: 10.1016/j.fbp.2014.05.006.

[110] Noor, N. M., Aziz, A. A., Sarmidi, M. R., and Aziz, R. 2013. The Effect of Virgin Coconut Oil Loaded Solid Lipid Particles (VCO-SLPS) on Skin Hydration and Skin Elasticity. Jurnal Teknologi (Sciences Engineering). 62(1): 39-43. DOI: $10.11113 /$ jt.v62.1248.

[1 11 1] Shahavi, M. H., Hosseini, M., Jahanshahi, M., Meyer, R. L., and Darzi, G. N. 2015. Evaluation of Critical Parameters for Preparation of Stable Clove Oil Nanoemulsion. Arabian. Journal of Chemistry. DOI: 10.1016/j.arabjc.2015.08.024.

[112] Zambaux, M. F., Bonneaux, F., Gref, R., Maincent, P., Dellacherie, E., Alonso, M. J., Labrude, P., and Vigneron, C. 1998. Influence of Experimental Parameters on the Characteristics of Poly(Lactic Acid) Nanoparticles Prepared by a Double Emulsion Method. Journal of Control Release. 50(1-3): 31-40. DOI: 10.1016/S0168-3659(97)00106-5.

[113] Arancibia, C., Riquelme, N., Zúñiga, R., and Matiacevich, S. 2017. Comparing the Effectiveness of Natural and Synthetic 
Emulsifiers on Oxidative and Physical Stability Of Avocado Oil-based Nanoemulsions. Innovative Food Science and Emerging Technology. 44: 159-166. DOl: 10.1016/j.ifset.2017.06.009.

[114] Pengon, S., Chinatangkul, N., Limmatvapirat, C., and Limmatvapirat, S. 2018. The Effect of Surfactant on the Physical Properties of Coconut Oil Nanoemulsions. Asian Journal of Pharmaceutical Science. 13(5): 409-414. DOI: 10.1016/j.ajps.2018.02.005

[115] Wiyani, L., Aladin, A., Yani, S., and Rahmawati. 2016. Stability of Virgin Coconut Oil Emulsion with Mixed Emulsifiers Tween 80 and Span 80. ARPN Journal of Engineering and Applied Science. 11 (8): 5198-5202.

[116] Juttulapa, M., Piriyaprasarth, S., Takeuchi, H., and Sriamornsak, P. 2017. Effect of High-Pressure Homogenisation on Stability of Emulsions Containing Zein And Pectin. Asian Journal of Pharmaceutical Science. 12(1): 21-27. DOl: 10.1016/j.ajps.2016.09.004.

[117] Hebishy, E., Buffa, M., Juan, B., Blasco-Moreno, A., and Trujillo, A. J. 2017. Ultra High-pressure Homogenized Emulsions Stabilised by Sodium Caseinate: Effects of Protein Concentration and Pressure on Emulsions Structure and Stability. LWT Journal. 76: 57-66. DOI: 10.1016/j.lwt.2016.10.045.

[1 18] Hao Bi, C., Lin Wang, P., Yu Sun, D., Ming Yan, Z., Liu, Y., Gang Huang, Z., and Gao, F. 2020. Effect of High-Pressure Homogenisation on Gelling and Rheological Properties of Soybean Protein Isolate Emulsion Gel. Journal of Food Engineering. DOI: 10.1016/j.jfoodeng.2020.109923.

[119] Cha, Y., Shi, X., Wu, F., Zou, H., Chang, C., Guo, Y., Yuan, M. and $Y u, C .2019$. Improving the Stability of Oil-in-Water Emulsions by Using Mussel Myofibrillar Proteins and Lecithin as Emulsifiers and High-pressure Homogenisation. Journal of Food Engineering. 258: 1-8. DOI: 10.1016/j.jfoodeng.2019.04.009

[120] Santos, D., Maurício, A., Sencadas, V., Santos, J., Fernandes, M., and Gomes, P. 2017. Spray Drying: An overview. IntechOpen.

httpdoi.org/10.1039/C7RA00172J\%0Ahttps://www.intechop en.com/books/advanced-biometric-technologies/livenessdetection-in-

biometrics\%0Ahttp://dx.doi.org/10.1016/j.colsurfa.201 1.12.01 4 (accessed Jul. 11, 2020).

[121] Korma, S. A., Wei, W., Ali, A. H., Abed., S. M.Zheng, L., Jin, Q., and Wang, X. 2019. Spray-dried Novel Structured Lipids Enriched with Medium-and Long-Chain Triacylglycerols Encapsulated with Different Wall Materials: Characterisation and stability. Food Research International. 116: 38-547. DOI: 10.1016/j.foodres.2018.08.071

[122] Onsaard, E., Putthanimon, J., Singthong, J., and Thammarutwasik, P. 2018. Oxidation Stability of Sesame Oil Encapsulated by Spray Drying. International Food Research Journal. 25(2): 784-792.

[123] Kha, T. C., Nguyen, M. H., Roach, P. D., and Stathopoulos, C. E. 2014. Microencapsulation of Gac Oil by Spray Drying: Optimisation of Wall Material Concentration and Oil Load
Using Response Surface Methodology. Drying Technology 32(4): 385-397. DOI: 10.1080/07373937.2013.829854.

[124] Laksono, S., and Kumalaningsih, S. P. 2000. Technical and Financial Studies for Choosing The Right Method of Coconut Milk Powder Production: Effect of Tween 80 and Soy Milk Concentration. International Journal of Agricultural Technology. 1 (3): 35-39.

[125] Manikantan, M. R., Kingsly Ambrose, R. P., and Alavi, S. 2016. Moisture Dependent Dynamic Flow Properties of Coconut Flours. International Journal Food Engineering. 12(6): 577-585. DOI: 10.1515/ijfe-2015-0325.

[126] Naik, A., Venu, G. V., Prakash, M., and Raghavarao, K. S. M. S. 2014. Dehydration of Coconut Skim Milk and Evaluation of Functional Properties. CYTA - Journal of Food. 12(3): 227-234. DOI: 10.1080/19476337.2013.833296.

[127] Rosida, D. F., Mulyani, T., and Septalia, L. R. 2016. A Comparative Study of Non-Dairy Cream Based on the Type of Leguminosae Protein Source in Terms of Physico Chemical Properties and Organoleptic. Agriculture Agricultural Science Procedia. 9: 431-439. DOI: 10.1016/j.aaspro.2016.02.160.

[128] Hassan, M. A. 1985. Production of Spray-dried Coconut Milk Powder. Pertanika Journal of Tropical Agricultural Science. 8(1): 127-130.

[129] Khedkar, S. S., Kalyankar, S.D, Deosarkar, C.D . 2016. Buffalo milk. In: Caballero, B., Finglas, P. M., and Toldrá, F. (Eds.). The Encyclopedia of Food and Health. 1: 522-528. Waltham: Academic Press.

[130] Aghbashlo, M., Mobli, H., Madadlou, A., and Rafiee, S. 2013. Fish oil Microencapsulation as Influenced by Spray Dryer Operational Variables. International Journal of Food Science \& Technology. 48(8): 1707-1713. DOI: 10.1111/ijfs.12141.

[131] Naik, A., Raghavendra, S. N., and Raghavarao, K. S. M. S. 2012. Production of Coconut Protein Powder from Coconut Wet Processing Waste and Its Characterisation. Applied Biochemistry and Biotechnology. 167(5): 1290-1302. DOI: 10.1007/s12010-012-9632-9.

[132] Mohammed, N. K., Tan, C. P., Manap, Y. A., Alhelli, A. M., and Hussin, A. S. M. 2017. Process Conditions of Spray Drying Microencapsulation of Nigella Sativa Oil. Powder Technology. 315: 1-14. DOI: 10.1016/j.powtec.2017.03.045.

[133] Fernandes, R. V. D. B., Borges, S. V., and Botrel, D. A. 2014. Gum Arabic/Starch/Maltodextrin/Inulin as Wall Materials on the Microencapsulation of Rosemary Essential Oil. Carbohydrate Polymers. 101(1): 524-532. DOI: 10.1016/j.carbpol.2013.09.083.

[134] Kirchberg, S., Abdin, Y., and Ziegmann, G. 201 1. Influence of Particle Shape and Size on the Wetting Behavior of Soft Magnetic Micropowders. Powder Technoloy. 207(1-3): 311 317. DOI: 10.1016/j.powtec.2010.11.012.

[135] Vijayasanthi, J., Adsare, S. R., Lamdande, A. G., Naik, A., Raghavarao, K. S. M. S., and Prabhakar, G. 2020. Recovery of Proteins from Coconut Milk Whey Employing Ultrafiltration and Spray Drying. Journal of Food Science and Technology. 57(1): 22-31. DOI: 10.1007/s13197-019-04025-9. 